\title{
A new species of lizard of the genus Eublepharis (Squamata: Eublepharidae) from India
}

\author{
Zeeshan A. Mirza', Rajesh V. Sanap ${ }^{1}$, David Raju², Atish Gawai ${ }^{3}$, and Prathamesh Ghadekar ${ }^{4}$ \\ ${ }^{1}$ Biodiversity Lab, National Centre for Biological Sciences, Tata Institute of Fundamental Research, Bangalore 560065, \\ Karnataka, India. E-mail: snakeszeeshan@gmail.com. \\ ${ }^{2}$ Valiyaparampil House, Kuzhimattom. PO Kottayam 686533, Kerala, India. \\ ${ }^{3}$ Near J. V. Mehta high school behind Ambika Krida Mandal, Taluka Khamgaon, District Buldana, Maharashtra, India. \\ ${ }^{4}$ G/6 Pancharatna, Manjarli, Badlapur (West), District Thane, Thane 421503, Maharashtra, India.
}

\begin{abstract}
A new species of lizard of the genus Eublepharis (Squamata: Eublepharidae) from India. We describe here a new species of the genus Eublepharis from the Satpura Hills in central India. The new species closely resembles E. fuscus, but can be differentiated from it by the following suite of characters: SVL $125-130 \mathrm{~mm}$; dome shaped tubercles lacking keels arranged in $\sim 20$ rows on dorsum, inter-tubercular space greater than width of a tubercle; 46-48 ocular fringe scales, three pale bands between the nuchal loop and caudal constriction; medial subdigital lamellae smooth; 13-14 preanal pores, which may be interrupted medially by a single poreless scale. Description of the new species sheds light on the limited knowledge of Eublepharis in India. We provide an identification key to the species of the genus Eublepharis.
\end{abstract}

Keywords: central India, identification key, leopard gecko, Satpura Hills, species description, taxonomy.

\begin{abstract}
Resumo
Uma nova espécie de lagarto do gênero Eublepharis (Squamata: Eublepharidae) da Índia. Descrevemos aqui uma nova espécie de lagarto do gênero Eublepharis das Montanhas Satpura, Índia central. A nova espécie assemelha-se intimamente a E. fuscus, mas pode ser distinguida desta pelo seguinte conjunto de caracteres: SVL 125-130 mm; tubérculos em forma de domo, sem quilhas, arranjados em $\sim 20$ fileiras no dorso, espaço intertubercular maior que a largura de um tubérculo; 46-48 escamas na franja ocular, três faixas claras entre a curva nucal e a constrição caudal; lamelas subdigitais mediais lisas; $13-14$ poros pré-anais, que podem estar interrompidos medialmente por uma única escama sem poro. A descrição da nova espécie aumenta o conhecimento limitado de Eublepharis na Índia. Fornecemos uma chave de identificação para as espécies do gênero Eublepharis.
\end{abstract}

Palavras-chave: chave de identificação, descrição de espécie, Índia central, lagartixa-leopardo, Montanhas Satpura, taxonomia.

Received 17 October 2014

Accepted 15 December 2014.

Distributed December 2014. 


\section{Introduction}

The old world lizard family Eublepharidae, commonly known as leopard geckos, is represented worldwide by six genera and 31 species (Grismer 1988, 1989, Uetz and Hošek 2014). Members of this family are secretive, strictly nocturnal and occur in a variety of habitats from arid to semi-arid ecosystems as well as high elevation forests and have a disjunct distribution in southwestern North America and northern Central America, sub-Saharan Africa and southern and eastern Asia (Grismer 1988, 1989, Jonniaux and Kumazawa 2008). In India, eublepharids are represented by the single genus Eublepharis Gray, 1827, comprising three species which exhibit a disjunct distribution: $E$. macularius Blyth, 1854 in Rajasthan state and Jammu and Kashmir state; E. fuscus Börner, 1974 in southern Gujarat state and North western Maharashtra state and E. hardwickii Gray, 1827 in Jharkhand state, West Bengal state and Odisha state (Figure 1) (Smith 1935, Grismer 1988, Das 1997, Mirza and Upadhye 2010). Leopard geckos are by far one of the least studied lizards in India, especially in comparison with gekkonid lizards. Monographic publications on these lizards, supported by integrated morphological and molecular data, are scarce, with the exception of Smith (1935), Börner (1974, 1981), Sharma (1980), Grismer (1988), Das (1997) and Mirza and Upadhye (2010), which are based entirely on morphology.

During a herpetological investigation of the Satpura Hills, central India, specimens of a Eublepharis sp. were collected which could not be attributed to the three known species from India (Figure 1). Previous workers identified this population as Eublepharis hardwickii (Khujaria 1986, Chandra and Gupta 2005a,b); however, doubts on the identity of this population were raised by Mirza and Upadhye (2010). Detailed comparison based on fresh collections and available museum material concluded that the disjunct population of Eublepharis from the Satpura Hills belongs to a new species. The present communication describes the Satpura Hills population as a new species and also adds notes on its phylogenetic affinity based on morphology following Grismer (1988).

\section{Materials and Methods}

Specimens were collected by hand, fixed in $8 \%$ formalin and stored in $70 \%$ ethanol. The largest male specimen from the series was selected as the holotype and has been deposited along with four paratypes in the collection of the Bombay Natural History Society, Mumbai. The skull was removed from a non-type specimen; tissue was dissolve in $4 \%$ potassium hydroxide, followed by manual cleaning using forceps and needles. This skull is deposited in the collection of BNHS. A radiograph of the holotype was taken with a Skanray ${ }^{\mathrm{TM}}$ Mobile X-ray at $40 \mathrm{kV}$ and $3.0 \mathrm{mAs}$ to obtain details of number of vertebrae and phalanges.

The following measurements were taken with digital calipers (to the nearest $0.1 \mathrm{~mm}$ ): snout-vent length (SVL; from tip of snout to vent), trunk length (TRL; distance from axilla to groin measured from posterior edge of forelimb insertion to anterior edge of hind-limb insertion), body width (BW; maximum width of body), crus length (CL; from base of heel to knee); tail length (TL; from vent to tip of tail), tail width (TW; measured at widest point of tail); head length (HL; distance between retroarticular process of jaw and snout-tip), head width (HW; maximum width of head), head height $(\mathrm{HH}$; maximum height of head, from occiput to underside of jaws), ear length (EL; longest diameter of ear); forearm length (FL; from base of palm to elbow); orbital diameter (OD; greatest diameter of orbit), nares to eye distance (NE; distance between anteriormost point of eye and nostril), snout to eye distance (SE; distance between anteriormost point of eye and tip of snout), eye to ear distance (EE; distance from anterior edge of ear opening to posterior corner of eye), internarial distance (IN; distance between nares), interorbital distance (IO; shortest 


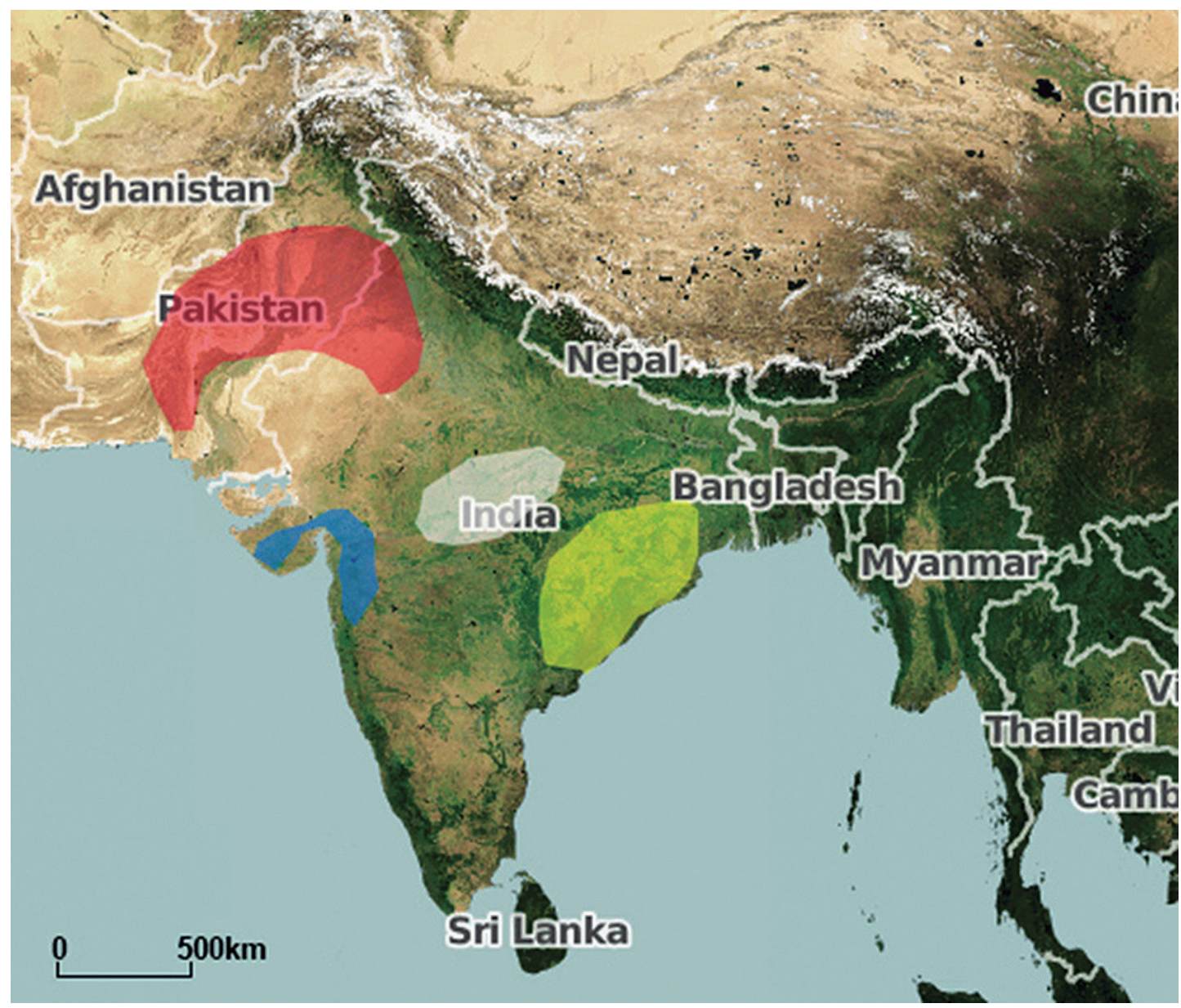

Figure 1. Map of the Indian subcontinent showing distribution of members of the genus Eublepharis: red - E. macularius, blue - E. fuscus, white - Eublepharis satpuraensis sp. nov., yellow - E. hardwickii. Modified after Grismer (1988).

distance between left and right supraciliary scale rows), pre-cloacal pores (PP), supralabials (SL), infralabials (IL), lamellae (MLam; lamellae on manus, Plam; lamellae on pes); left (L), right (R). Interorbital scale count includes small granular scales and excludes intermixed tubercles. Scale counts and external observations of morphology were made using an Olympus ${ }^{\mathrm{TM}} \mathrm{SZ} 40$ dissecting microscope. Institutional acronyms used in the manuscripts are as follows: BNHS: Bombay Natural History Society, Mumbai; NCBS:
National Centre for Biological Sciences, national collection research facility, Bangalore; ZSIK: Zoological Survey of India, Kolkata; CAS: California Academy of Sciences, San Francisco; ZIL: Zoological Institute, Academy of Sciences, St. Petersburg; ZSIJ: Zoological Survey of India, Jabalpur. The LSID for this publication is urn:1sid:zoobank.org:pub:D8432AE7-351F-473FA067-D6DC581C10AF. Morphological details for congeners were derived from specimens listed in Appendix I and from the following publications: 
Smith (1935), Grismer (1988, 1991) and Mirza and Upadhye (1988). Details of E. angramainyu and E. turcmenicus were derived from high resolution images obtained from Noel Graham (CAS herpetology section).

\section{Results}

Eublepharis satpuraensis sp. nov.

Eublepharis hardwickii: Khujaria 1986; Chandra and Gupta 2005a,b

Eublepharis sp.: Mirza and Upadhye 2010

(Figures 2-7, Figure 10F, Table 1)

Holotype.-Adult male BNHS 2301, Pachmarhi town, Satpura Tiger Reserve, Madhya Pradesh state, India; collected by Rajesh Sanap, Zeeshan Mirza and David Raju on 9 May 2014.

Paratypes.-Adult male BNHS 2302, adult female BNHS 2303, same data as holotype; juvenile male BNHS 2304, juvenile female BNHS 2305, collected from Popatkhed, Amravati district, Maharashtra state, India by Krishna Khan, Atish Gawai and Kiran Bawaskar on 14 April 2014.

Other material.-ZSIK 25321 \& ZSIJ V-3276a adult male, 3276b subadult, 3276c juvenile from Bandhavgarth National Park, Madhya Pradesh state, India; ZSIJ 1388, a juvenile from Pachmarhi, Satpura Tiger Reserve, Madhya Pradesh state, India. Skull NCBS AG801 of a subadult male from Pachmarhi, Satpura Tiger Reserve, Madhya Pradesh state, India.

Etymology.-The new species is named after the Satpura Hills in central India, where the type locality is located.

Diagnosis.-A medium sized species of Eublepharis (maximum SVL $130 \mathrm{~mm}$ ) differing from congeners in the following suite of characters: SVL 125-130 mm; dome shaped tubercles lacking keels arranged in $\sim 20$ rows on dorsum, inter-tubercular space more than width of a tubercle; 46-48 ocular fringe scales, three pale bands between the nuchal loop and caudal constriction; median subdigital lamellae smooth; 13-14 preanal pores which may be interrupted medially by a single poreless scale.

Description of the holotype (Figures 2-5).Adult male BNHS 2301. The holotype is in good condition with a regenerated tail. SVL $126.3 \mathrm{~mm}$ (Figure 3A,B). Head short $(\mathrm{HL} / \mathrm{SVL}=0.26$ ), moderately wide $(\mathrm{HW} / \mathrm{HL}=0.74)$, not strongly depressed $(\mathrm{HD} / \mathrm{HL}=0.48)$ (Figure 4A,B), distinct from neck. Loreal region slightly inflated, canthus rostralis not prominent. Snout short $(\mathrm{SE} / \mathrm{HL}=0.36)$; longer than eye diameter $(\mathrm{OD} / \mathrm{SE}=0.55)$; scales on snout and canthus rostralis heterogeneous (small granular scales intermixed with large hexagonal scales), large, unkeeled, juxtaposed; slightly larger than those on forehead and interorbital region; occipital and temporal region with much smaller, granular scales intermixed with larger tubercles. Eye small $(\mathrm{OD} / \mathrm{HL}=0.20)$; pupil vertical in life; eyelid fringe with 48 scales. Ear opening deep, oval in shape, small $(\mathrm{EL} / \mathrm{HL}=0.15)$; eye to ear distance greater than diameter of eyes $(\mathrm{EE} / \mathrm{OD}=$ 1.69). Rostral wider than long, divided by rostral groove for more than half its length; supranasals two, supra-prenasal one, one prenasal, four postnasals and supralabial I surrounding nasal. Supranasals separated by three internasals; supralabial I in broad contact with nasal; two to three rows of scales separate orbit from supralabials. Mental enlarged, subtriangular, wider than rostral and wider than long; one pair of postmentals, large, subrectangular; bordered by the mental, infralabial I and six scales larger than those on the throat. Chin shields are flat, smooth and are slightly smaller than postmental shield.

Supralabials to midorbital position 9, supralabials to angle of jaws 10 ; infralabials to angle of jaws 8 ; interorbital scale rows between left and right superciliaries in front of the eye 22, at midorbit 30. Body relatively slender, fairly 
elongate $(\mathrm{TRL} / \mathrm{SVL}=0.49)$ without ventrolateral folds. Distinct axillary groove present. Dorsal scales on trunk subequal, granular, juxtaposed, intermixed with large unkeeled dome shaped tubercles arranged in $\sim 20$ rows. Inter-tubercular space greater than width of a tubercle (Figure 4E).

Ventral scales larger than dorsal scales, smooth, imbricate, slightly larger on abdomen than on chest; midbody scale rows across belly to lowest row of tubercles 22-25; gular region with still smaller, juxtaposed, smooth scales. A continuous series of fourteen precloacal pores, femoral pores absent (Figure 3B).

Scales on palm and sole smooth; slightly elongate on forelimb and dorsal aspect of hindlimb, 3-4 times larger than dorsal granules, keeled, imbricate; those on inner surface of hindlimb slightly smaller, keeled. Fore and hindlimbs relatively short, slender; forearm and crus short $(\mathrm{FL} / \mathrm{SVL}=0.15 ; \mathrm{CL} / \mathrm{SVL}=0.16)$; digits elongate, clawed; subdigital lamellae smooth, entire, unnotched; interdigital webbing absent. Lamellae: MLam11-14-16-16-16 (left), PLam 10-15-18-18-16 (left); relative length of digits (measurements in mm): IV (3.4) > III (3.3) =II (3.3) > V (2.0) > I (1.9) (left manus); IV (4.8) $>\mathrm{V}(3.7)=$ III (3.7) > II (3.0) > I (2.2) (left pes) (Figure 4C,D).

Tail cylindrical, flattened ventrally, tail longer than snout-vent length $(\mathrm{TL} / \mathrm{SVL}=0.54)$, nearly $75 \%$ of tail regenerated; regenerated portion of the tail stouter than original tail; tail base distinctly swollen when viewed ventrally; a pair of post-cloacal spurs present on each side, anterior spur large, conical, posterior spur half the size of the anterior spur, dome shaped and depressed; original tail covered above with flat, squarish scales, juxtaposed; ventral scales much larger than dorsal scales, smooth, squarish in shape. Regenerated portion of tail covered dorsally with rectangular, convex scales. Original tail with eight large, smooth, sub-conical tubercles arranged in a transverse row in dorsal and lateral surface of tail; those on the middorsum smaller and located on the posterior half of each segment (Figure 3A,B).
Osteology.-Phalangeal formulae 2-3-4-5-3 for manus and 2-3-4-5-4 for pes. Presacral vertebrae 26 , including two cervical vertebrae lacking ribs. Pterygoid-palatine suture straight. Supra-temporal bone small. Basioccipital bone smooth, with a smooth rounded posterior margin, longitudinally directed crest absent.

Coloration in preservative (Figure 3A,B).Dorsum brown with three pale bands. Pale bands with brown spots and blotches. Head with reticulations dorsally, limbs pale with brown spots dorsally. A pale mid-dorsal vertebral stripe running from the nape to the pale band at the groin. Original tail brown with a few dark and light patches which merge to give a diffused reticulate appearance. Regenerated tail background color black with pale reticulations on dorsal surface. Venter straw color throughout, chin with a few scattered light brown spots and a mid-gular spotless band. Ventral aspect of original tail with a pair of brown patches on their lateral portion; venter of regenerated tail with extension of dorsal reticulated pattern merging into the mid-ventral unpatterned region.

Coloration in life.-Coloration in life more vivid than in preservative. Pale bands and reticulations are yellow and the background color is a much darker shade of brown (Figure 2).

Variation.-Measurements of holotype and paratypes are in Table 1. In addition to measurements, the paratypes differ from the holotype as follows: male paratype BNHS 2304 has (i) a gap of a single non-pored scale in the series of precloacal pores, (ii) supralabials 10-11 and infralabials 8-10, (iii) subdigital lamellae on manus I 9-10, II 13-15, III 15-17, IV 15-18, V 12-16; on pes I 9-13, II 12-15, III 17-21, IV 18-22, V 16-2; juvenile paratypes BNHS 2304 and BNHS 2305 lack spots and reticulation as in the adults (Figures 6, 7B, 10F); female paratypes possess three post-cloacal spurs as opposed to two in the male holotype. 


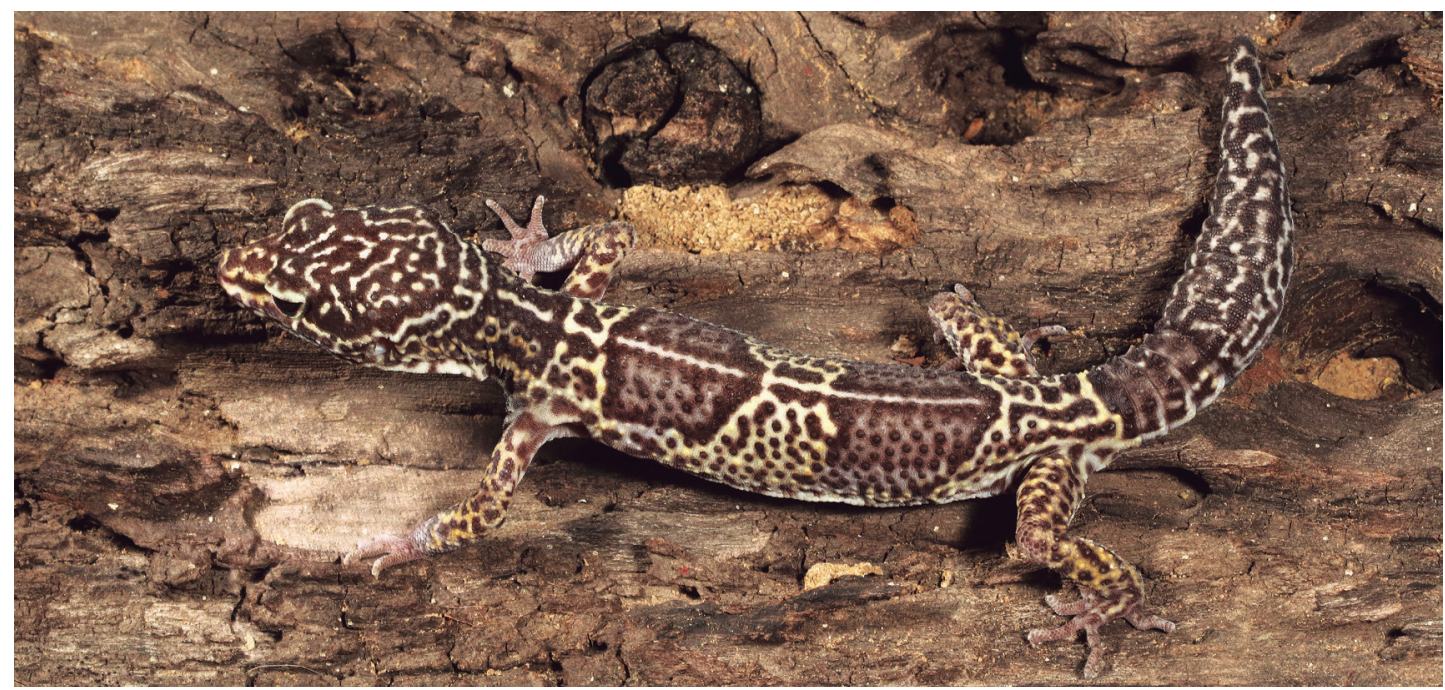

Figure 2. Eublepharis satpuraensis sp. nov. holotype male BNHS 2301 in life. Photo by Zeeshan A. Mirza.

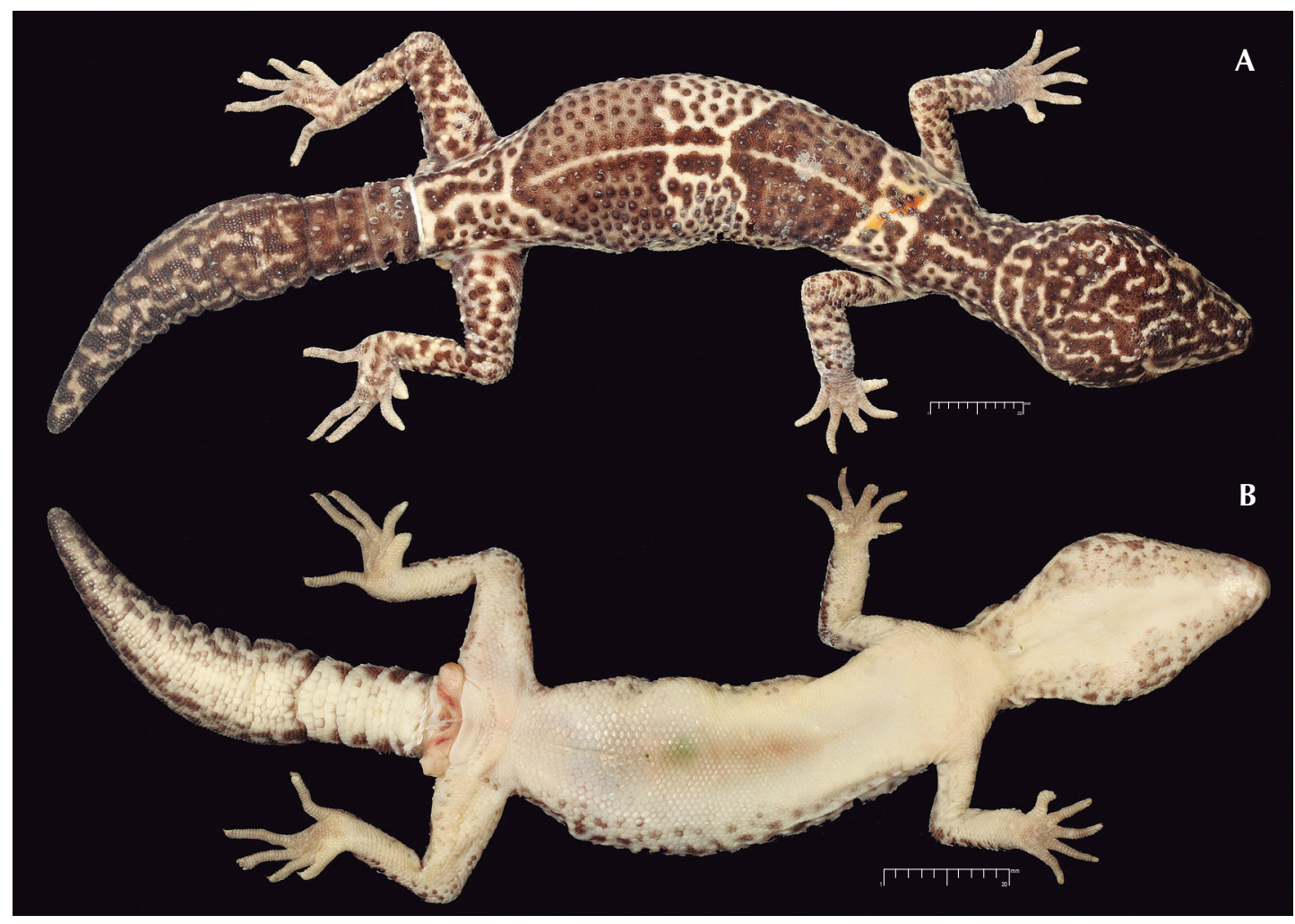

Figure 3. Eublepharis satpuraensis sp. nov. holotype male BNHS 2301, (A) dorsal view, (B) ventral view. Scale bar $20 \mathrm{~mm}$. 


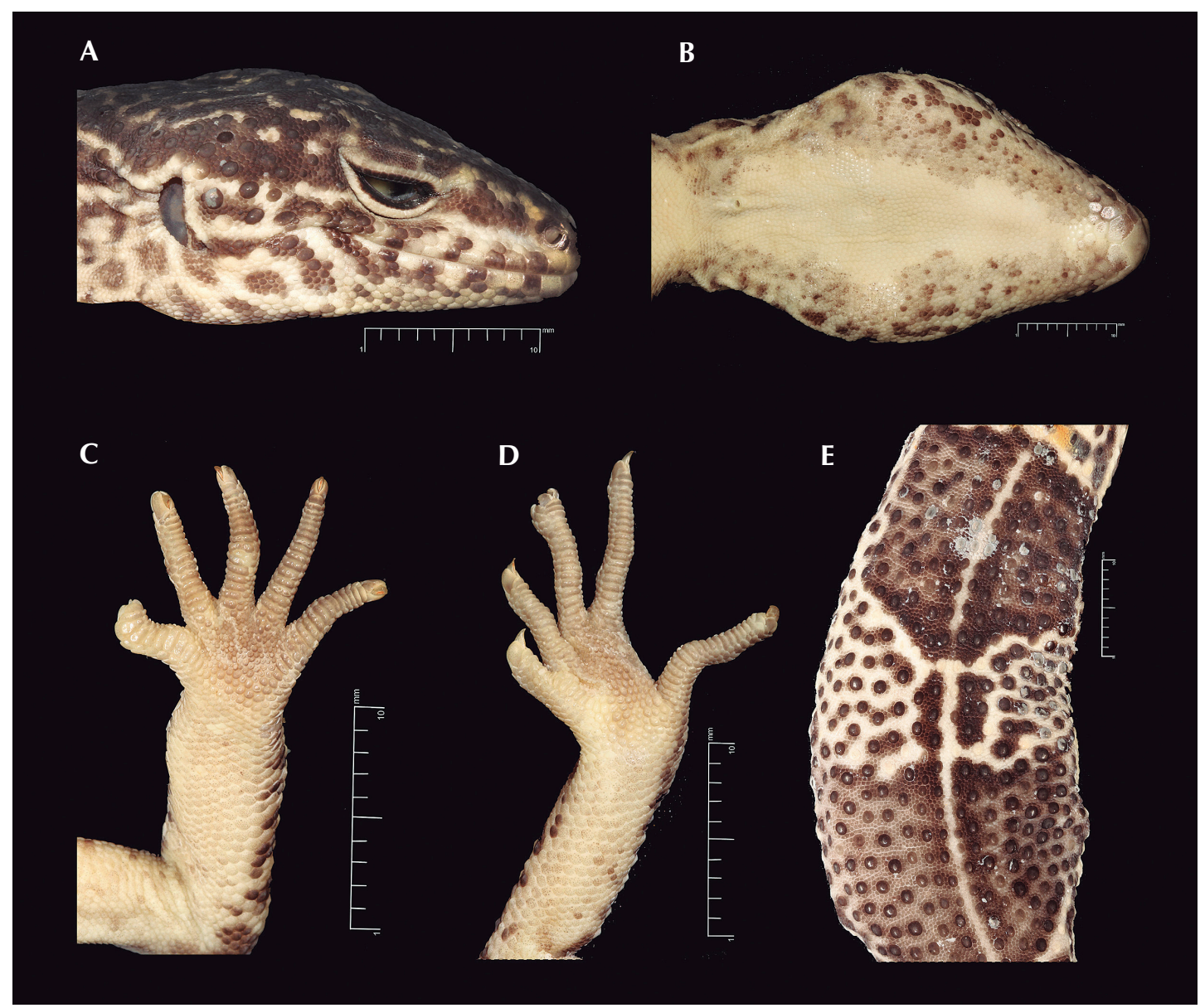

Figure 4. Eublepharis satpuraensis sp. nov. holotype, male BNHS 2301, (A) lateral view of head, (B) ventral view of head, $(\mathbf{C})$ ventral view of manus, (D) ventral view of pes, (E) dorsal view of trunk. Scale bar $10 \mathrm{~mm}$.

Natural history and distribution.-The holotype along with the two paratypes from Madhya Pradesh were collected during night walks along rocky outcrops. The holotype was found actively moving along boulders near a dry streambed. The female paratype BNHS 2303 was taken from a burrow under a boulder along a road. In addition to the type specimens, ten other individuals were observed during the survey. Most individuals were seen moving near crevices or burrows and would retreat with the slightest disturbance. A sub-adult male was offered scorpion (Isometrus sp.) and grasshoppers in captivity, which were readily accepted. The new species, like other members of the genus, are strictly nocturnal and are secretive in nature. Very few residents in the vicinity of the type locality are aware of the presence of such a species. Due to its conspicuous coloration, this species is regarded as poisonous and is often killed when encountered by locals. The new species is presently known from Pachmarhi 


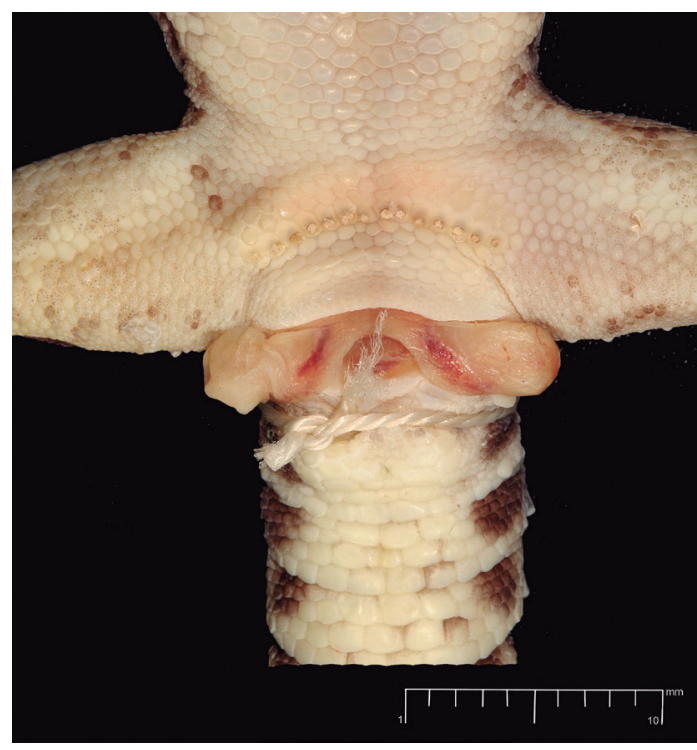

Figure 5. Eublepharis satpuraensis sp. nov. holotype, male BNHS 2301, ventral view of cloacal region showing pre-cloacal pores. Scale bar $10 \mathrm{~mm}$.
(Figure 8A) and surrounding areas in Satpura Tiger Reserve $\left(22.493853^{\circ} \mathrm{N}, 78.194290^{\circ} \mathrm{E}\right)$, Bhopal $\left(23.257516^{\circ} \mathrm{N}, 77.427313^{\circ} \mathrm{E}\right)$, Melghat Tiger Reserve $\left(21.330843^{\circ} \mathrm{N}, 77.089126^{\circ} \mathrm{E}\right.$; Figure 8B), Pench Tiger Reserve $\left(21.769338^{\circ} \mathrm{N}\right.$, $79.304909^{\circ}$ E), Bandhavgarh Tiger Reserve $\left(23.671783^{\circ} \mathrm{N}, 81.038122^{\circ} \mathrm{E}\right)$ and Jabalpur $\left(23.092208^{\circ} \mathrm{N}, 79.902936^{\circ} \mathrm{E}\right)$. Elevation ranges from 390 to $1350 \mathrm{~m}$. Based on the present known localities and based on exploratory distribution analysis using Maxent the new species appears to be distributed in the Satpura and Vindhya hill ranges (Figure 9). Forest types at the known localities are Southern moist mixed deciduous forest, Southern dry mixed deciduous forest and Dry peninsular sal forest; the major species are Tectona grandis, Shorea robusta, Bauchania latifolia, Termanalia arjuna, Madhuca indica and Rauwolfia serpentiana (Champion and Seth 2005).

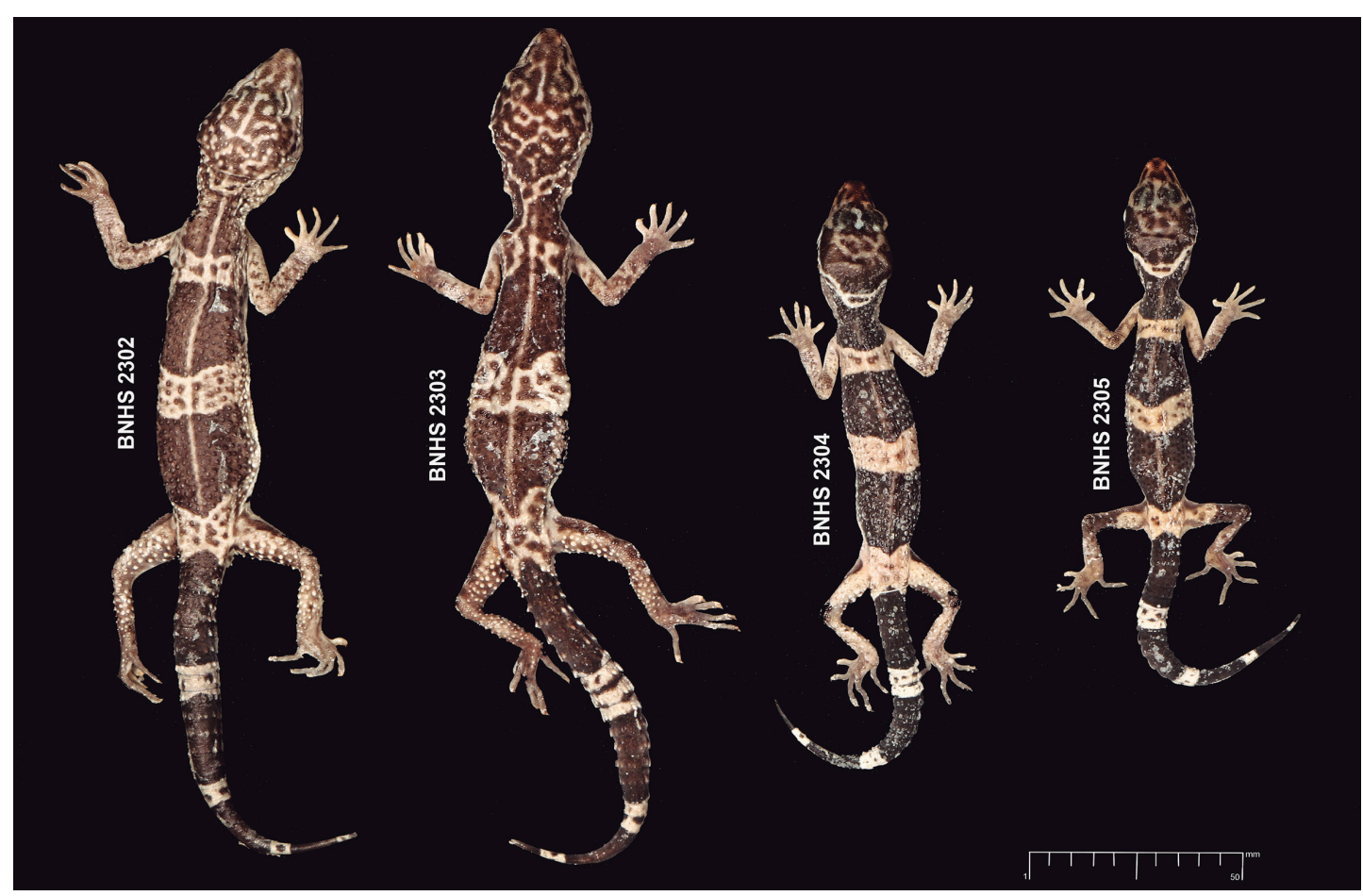

Figure 6. Dorsal view of paratypes of Eublepharis satpuraensis sp. nov. Scale bar 50 mm. 

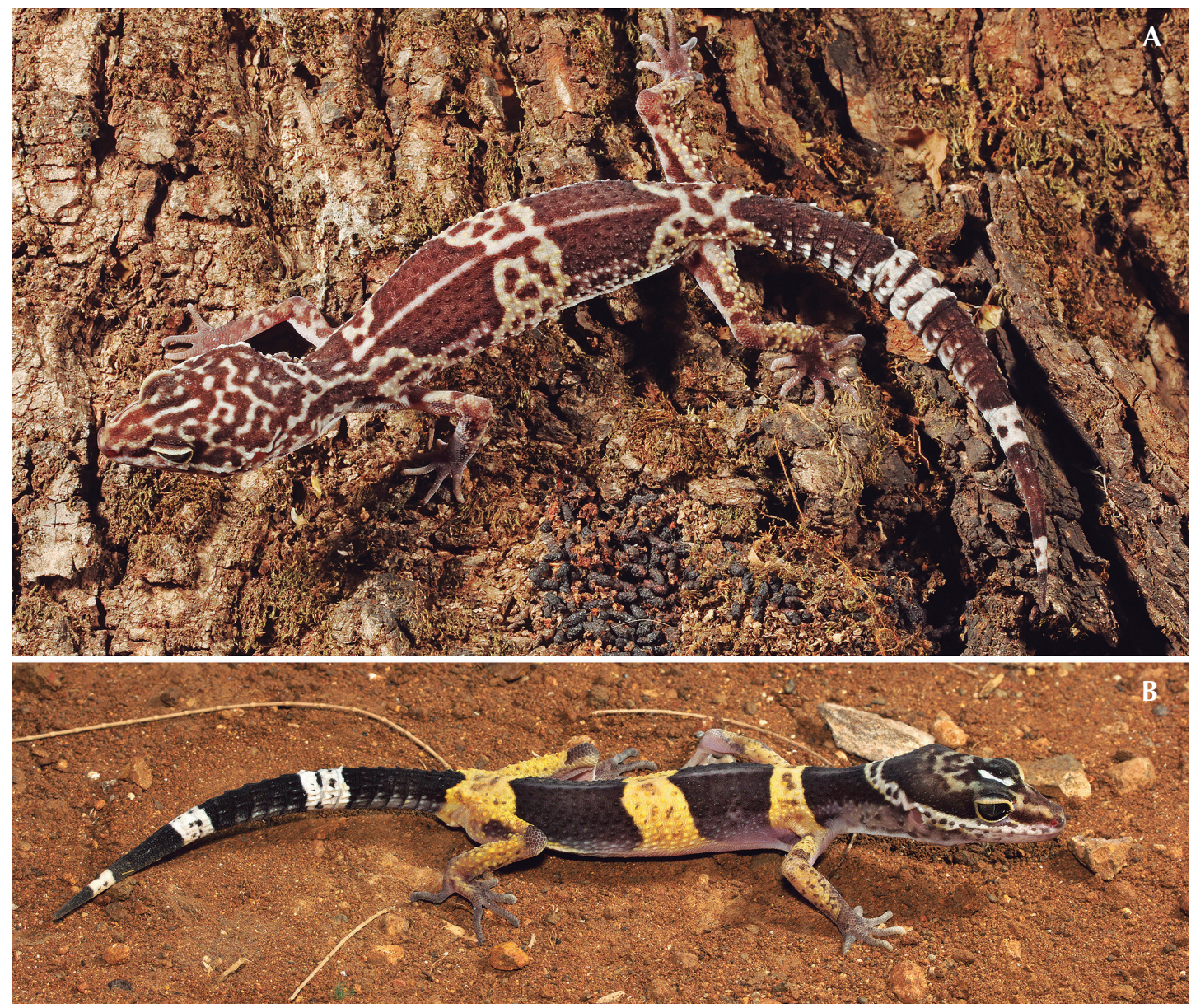

Figure 7. Eublepharis satpuraensis sp. nov. (A) paratype, female BNHS 2303 in life, (B) paratype, juvenile male BNHS 2304 in life. Photos: (A) Zeeshan Mirza, (B) Rajesh Sanap.

Comparison.-Eublepharis satpuraensis sp. nov. can be differentiated from its congeners based on differing or non-overlapping characters as follows: SVL 125-130 mm (vs. E. macularius SVL $170 \mathrm{~mm}$, E. fuscus SVL $252 \mathrm{~mm}, E$. angramainyu SVL $150 \mathrm{~mm}$ ); dorsal tubercles dome shaped, unkeeled, not depressed (vs. feebly keeled depressed tubercles in E. fuscus, tubercles keeled in E. turcmenicus, tubercles large, flat and in contact with one another in E. hardwickii); three pale bands between the nuchal loop and caudal constriction (vs. two pale bands in $E$. fuscus and E. hardwickii); subdigital lamellae smooth (vs. subdigital lamellae tuberculate in $E$. macularius); dorsal scales on regenerated tail flat and rectangular (vs. circular scales in $E$. macularius, E. angramainyu and E. turcmenicus); eyelid fringe scales 45-48 (vs. 54-55 in $E$. turcmenicus); adult background color brown with pale yellow bands bearing reticulations on head and trunk (vs. dark brown spots on a pale background lacking reticulations in E. macularius, 

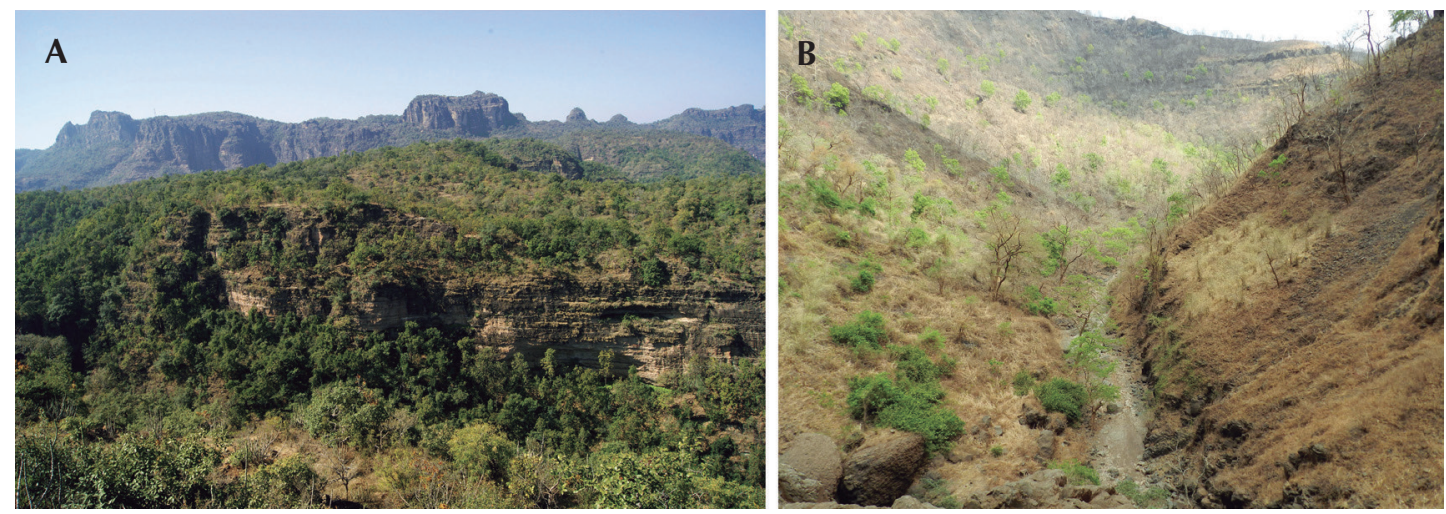

Figure 8. Habitat at the type locality in the Satpura Tiger Reserve (A), and the Melghat Tiger Reserve (B). Photos: (A) David Raju, (B) Vikram Vyawhare.

adults with alternating dark and pale bands lacking spots or reticulations in E. hardwickii) (Figure 10). Eublepharis satpuraensis sp. nov. further differs from E. angramainyu in having a straight pterygoid-palatine suture (vs. V-shaped in $E$. angramainyu); from $E$. hardwickii by the presence of a supratemporal bone (vs. absent in $E$. hardwickii); from E. macularius, E. fuscus and E. turcmenicus in having a smooth basioccipital bone lacking a longitudinally directed crest (vs. with a crest in E. macularius, E. fuscus and E. turcmenicus) and having a smooth rounded posterior margin (vs. a sharp transverse ridge in E. hardwickii).
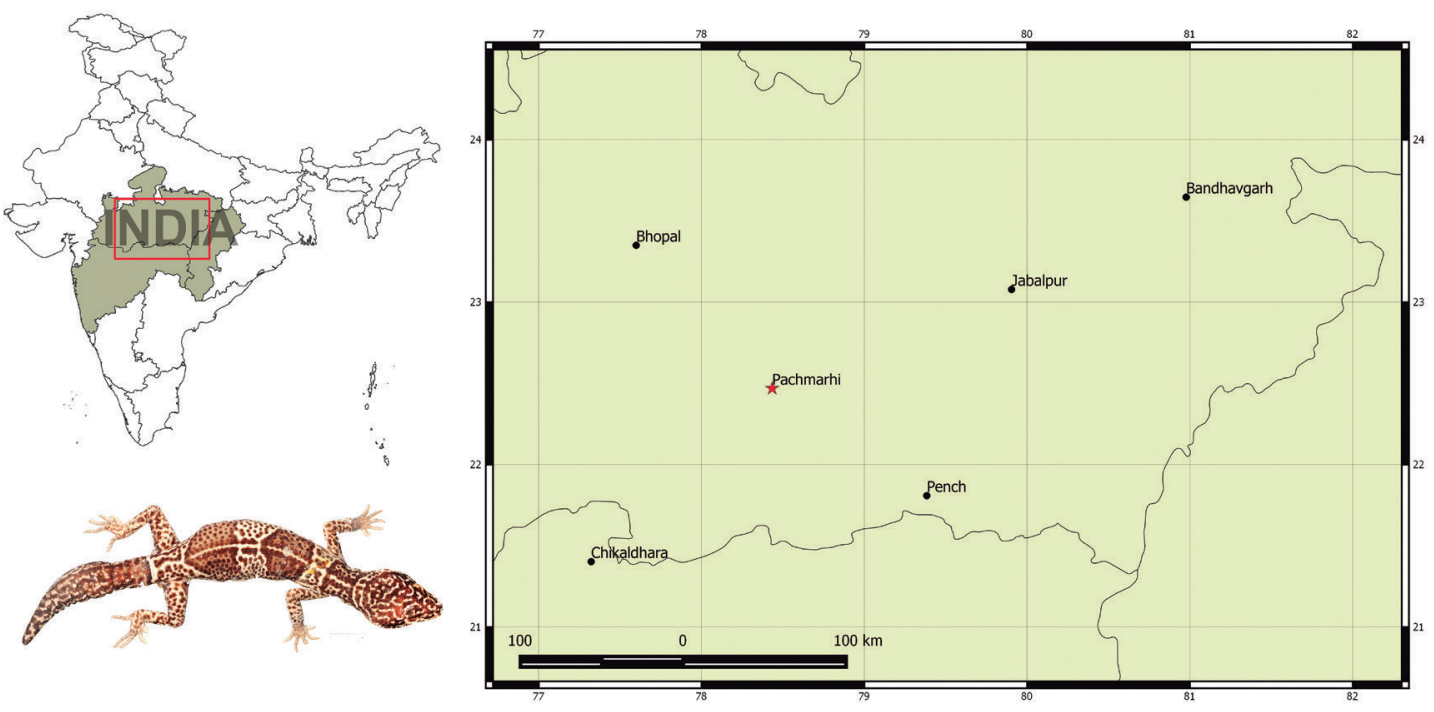

Figure 9. Map showing type locality and distribution of Eublepharis satpuraensis sp. nov. Type locality indicated by a red solid star. Inset map shows the known localities in black circles. 


\section{Discussion}

Despite advances in molecular phylogenetics of major saurian groups, relationship among members of the genus Eublepharis remains unresolved with the exception of work by Grismer (1988, 1991), Ota et al. (1999) and Jonniaux and Kumazawa (2008). However, studies conducted by Ota et al. (1999) and Jonniaux and Kumazawa (2008) included only one and two species respectively of the five known species of Eublepharis. Eublepharis satpuraensis sp. nov. appears to be closely related to E. fuscus in sharing similar tubercles, reticulate body pattern and smooth digital lamellae.
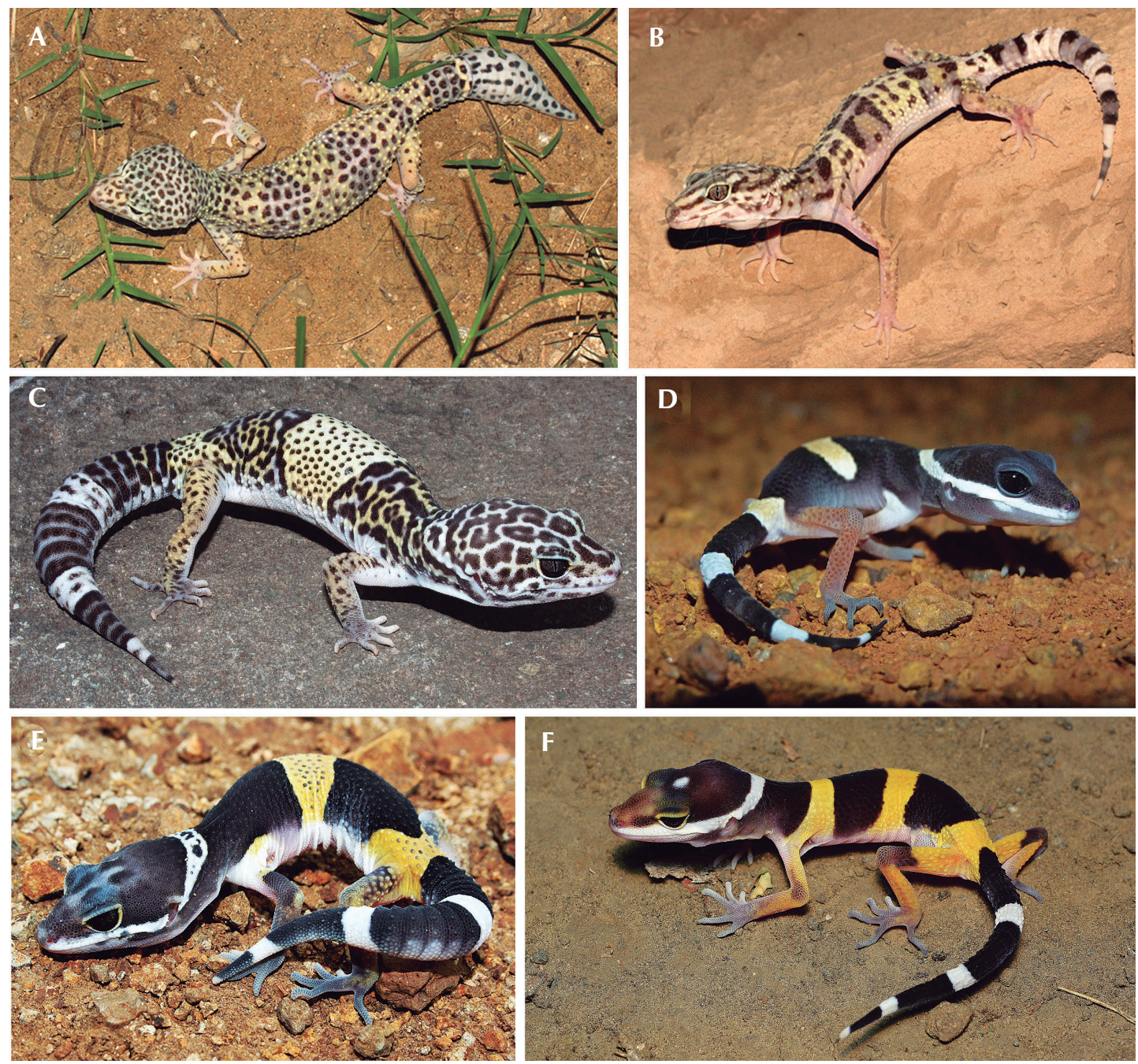

Figure 10. Coloration and markings of Eublepharis spp. in life. (A) Adult E. macularius, (B) adult E. angramainyu, (C) adult E. fuscus, (D) juvenile E. hardwickii, (E) juvenile E. fuscus, (F) juvenile E. satpuraensis sp. nov. Photos: (A, B) Barbod Safaei, (C) Zeeshan Mirza, (D) Vivek Sarkar, (E) Raman Upadhye, (F) Krishna Khan. 
Mirza et al.

Table 1. Morphometric and meristic data for the type series of Eublepharis satpuraensis sp. nov. All measurements in $\mathrm{mm}$; * indicates broken, ** indicates regenerated portion.

\begin{tabular}{|c|c|c|c|c|c|}
\hline \multirow{2}{*}{$\begin{array}{l}\text { Specimens } \\
\text { Number }\end{array}$} & \multirow{2}{*}{$\begin{array}{l}\text { Holotype } \\
\text { BNHS } 2301\end{array}$} & \multicolumn{4}{|c|}{ Paratypes } \\
\hline & & BNHS 2302 & BNHS 2303 & BNHS 2304 & BNHS 2305 \\
\hline Sex & male & male & female & male & female \\
\hline SVL & 126.3 & 125.3 & 130.1 & 95.4 & 88.5 \\
\hline TRL & 63.1 & 59.4 & 55.5 & 45.9 & 42.4 \\
\hline BW & 23.9 & 21.7 & 21.2 & 14.4 & 15.0 \\
\hline $\mathrm{CL}$ & 21.4 & 20.1 & 21.5 & 16.6 & 15.4 \\
\hline TL & $68.59\left(51.70^{* *}\right)$ & 96.3 & 101.9 & 85.2 & 76.9 \\
\hline TW & 15.1 & 10.0 & 8.1 & 6.4 & 6.5 \\
\hline $\mathrm{HL}$ & 33.3 & 31.4 & 28.6 & 23.9 & 20.4 \\
\hline HW & 24.9 & 22.0 & 22.8 & 15.9 & 15.9 \\
\hline $\mathrm{HH}$ & 16.2 & 13.6 & 13.3 & 11.9 & 10.5 \\
\hline $\mathrm{FL}$ & 19.5 & 17.8 & 17.7 & 14.4 & 12.3 \\
\hline OD & 6.8 & 6.2 & 6.3 & 4.3 & 4.6 \\
\hline NE & 7.7 & 9.0 & 8.6 & 7.4 & 7.3 \\
\hline SE & 12.2 & 11.4 & 11.6 & 10.1 & 8.2 \\
\hline $\mathrm{EE}$ & 11.6 & 10.5 & 10.3 & 8.7 & 7.8 \\
\hline EL & 5.3 & 5.2 & 4.9 & 3.9 & 3.2 \\
\hline IN & 4.0 & 4.6 & 5.1 & 5.1 & 4.6 \\
\hline $1 \mathrm{O}$ & 12.1 & 8.8 & 9.0 & 7.8 & 7.3 \\
\hline \multicolumn{6}{|l|}{ Lamellae } \\
\hline L Mlam & 11-14-16-16-16 & $10-13-15-18-14$ & $12-14-15-17-15$ & $10-15-17-17-16$ & $9-14-16-17-14$ \\
\hline R Mlam & $10-15-4 *-15-15$ & $9-13-17-17-12$ & $10-14-15-16-14$ & $10-14-16-17-16$ & $10-14-16-15-15$ \\
\hline L Plam & $10-15-18-18-16$ & $10-14-18-20-21$ & $13-14-18-21-20$ & $11-15-19-22-20$ & $10-15-20-22-21$ \\
\hline R Plam & $6 *-12-17-19-18$ & $9-14-18-22-20$ & $10-15-21-22-22$ & $11-15-19-22-20$ & $11-14-17-21-21$ \\
\hline \multicolumn{6}{|l|}{ SL } \\
\hline L & 10 & 10 & 11 & 10 & 10 \\
\hline$R$ & 10 & 10 & 10 & 10 & 10 \\
\hline \multicolumn{6}{|l|}{ IL } \\
\hline L & 8 & 9 & 10 & 9 & 9 \\
\hline $\mathrm{R}$ & 10 & 9 & 9 & 9 & 9 \\
\hline Pores L/R & 14 & 13 & - & 13 & - \\
\hline
\end{tabular}


Jonniaux and Kumazawa (2008) stated that the lineage that gave rise to Eublepharis evolved in Asian forests 100 MYA and likely invaded India after the accretion of the Indian plate to mainland Eurasia between 55-66 MYA (Briggs 2003). As demonstrated by Jonniaux and Kumazawa (2008), eublepharid radiation moved from east to west, the lineage of the genus Eublepharis invaded India and dispersed westwards from forested areas to arid regions. As understood by the distribution of extant species, morphological characters (Grismer 1988) and available molecular data (Jonniaux and Kumazawa 2008), we hypothesize that $E$. hardwickii shared a common ancestor with other species of the genus, of which one lineage gave rise to $E$. hardwickii and the other to the clade containing E. satpuraensis sp. nov., E. fuscus, E. macularius, E. turcmenicus and $E$. angramainyu. However these results are preliminary and must be tested using molecular data. Furthermore, skull osteology was determined from a single juvenile specimen and needs additional material for consistency and variation in characters.

E. satpuraensis sp. nov. has been referred to as E. hardwickii and/or E. macularius by previous workers (Khujaria 1986, Chandra and Gupta 2005a,b). Specimens ZSIJ V-3276a-c examined by Khujaria (1986) from Bandhavgarh and ZSIJ 1388 by Chandra and Gupta (2005a,b) from Pachmarhi Biosphere Reserve, attributed to E. hardwickii, clearly show the presence of three pale bands between the nuchal loop and caudal constriction (vs. two in E. hardwickii), reticulate pattern in adult specimens (reticulate patterns absent in E. hardwickii), presence of dome shaped unkeeled tubercles (vs. large, flat tubercles in E. hardwickii) which are diagnostic characters of E. satpuraensis sp. nov. Although E. hardwickii has been included in the list of reptiles of Madhya Pradesh (Chandra and Gupta 2005a,b), in light of the present study we attribute all old records of E. hardwickii to the new species and remove it from the reptile list of the state. It is likely that the new species may be found in northern Chhattisgarh, western Bihar and southern Uttar Pradesh in addition to the present records from Madhya Pradesh and northern Maharashtra and surveys in suitable habitat must be conducted to evaluate its presently assumed allopatric distribution.

Eublepharid lizards, commonly known as 'leopard geckos', are a major part of the reptile pet trade and are sought after by many enthusiasts and traders, although they remain poorly studied in their natural habitat. Description of a new species of eublepharid lizard from India highlights the need for dedicated herpetofaunal surveys throughout the country and especially of hill ranges like the Satpura Hills, which have been shown to be of great importance in biodiversity. The new discovery fills the large gap in the distribution of Eublepharis species in eastern and western India. Regardless of its large size, distinct markings and other morphological characters, E. satpuraensis sp. nov. was wrongly identified by previous workers (Khujaria 1986, Chandra and Gupta 2005a,b); this shows the need for a detailed revision of the genus Eublepharis based on morphological and molecular data.

The last decade has seen a sudden rise in the number of publications on Indian herpetofauna, largely concerned with the Western Ghats (Giri and Bauer 2008, Giri et al. 2009, Mirza and Sanap 2014, Mirza et al. 2014). Description of a new leopard gecko as well as of other reptiles from India in the recent past highlights the poor nature of herpetofaunal documentation in the country. With respect to this, we advocate dedicated herpetofaunal explorations throughout the country to evaluate the diversity of reptiles in India. Further dedicated herpetofaunal exploration using an integrated taxonomic approach will help elucidate the disjunct distribution of eublepharids in India and may even perhaps result in the discovery of additional undescribed species filling gaps in distribution of the genus Eublepharis. 


\section{Key to species of the genus Eublepharis}

1a. Dorsal tubercles large and flat, almost in contact; dorsal reticulate patterns absent; a single pale band between the nuchal loop and caudal constriction E. hardwickii

1b. Dorsal tubercles small, keeled or smooth, not in contact; dorsal dark and pale bands with reticulations or spots

2a. Dorsal tubercles keeled; precloacal pores interrupted medially by

1-4 non-pored scales

E. turcmenicus

2b. Dorsal tubercles smooth to feebly keeled; precloacal pores not interrupted medially 3

3a. A single pale band between the nuchal loop and caudal constriction E. fuscus

$3 \mathrm{~b}$. More than one pale band between the nuchal loop and caudal constriction 4

4a. Subdigital lamellae tuberculate E. macularius

4b. Subdigital lamellae smooth 5

5a. Regenerated portion of tail with circular and slightly convex dorsal scales; nuchal loop not reaching posterior edge of the eye E. angramainyu

5b. Regenerated portion of tail with rectangular and convex dorsal scales; nuchal loop extending anteriorly to the eyes and along supralabials to snout tip

E. satpuraensis

\section{Acknowledgments}

We thank the Rufford Small Grant for funding the project during which the new species was found. Special thanks to the Forest Department of Madhya Pradesh: Narendra Kumar (PCCF, wildlife and Chief Wildlife Warden), Dr. Suhas Kumar (APCCF wildlife), R. P. Singh (Field Director, Satpura Tiger Reserve) for necessary permissions to carry out research in Madhya Pradesh. Hashim Tyabji (Forsyth Lodge) for logistic support and permission to conduction surveys on his property. Rahul Khot (BNHS, Mumbai), Director of ZSI (Kolkata), Kaushik Deuti (ZSI, Kolkata), P. M. Sureshan (ZSI, Calicut) and S. Sambath (ZSI, Jabalpur) helped with access to specimens and registration of the type specimens. We extend our deepest gratitude to Krishna Khan and Kiran Bavaskar for help during fieldwork at Amravati and to Raman Upadhye for help with literature and distribution data of Eublepharis. Raman Upadhye, Vivek Sarkar, Krishna Khan, Vivek Sharma and Barbod Safaei shared images of Eublepharis species. Surya Ramachandran helped with fieldwork in Madhya Pradesh. Special thanks to Saunak Pal for reviewing the final draft of the manuscript and discussion on the topic from which the ms benefited greatly. Noel Graham provided images of specimens of Eublepharis in the collection of the California Academy of Science, San Francisco. Lee Grismer and Aaron Bauer provided valuable and inaccessible literature. The manuscript greatly benefited from constructive comments from Stephen Mohany and two anonymous reviewers. 


\section{References}

Börner, A. R. 1974. Einneuer Lidgecko der Gattung Eublepharis Gray 1827. Miscellaneous Articles in Saurology 4: 7-14.

Börner, A. R. 1981. Third contribution to the systematics of the southwest Asian lizards of the geckonid genus Eublepharis Gray, 1827: Further materials from the Indian subcontinent. Saurologica 3: 1-7.

Champion, H. G. and S. K. Seth. 2005. A Revised Survey of the Forest Types of India. Published by Government of India Press.

Chandra, K. and Y. N. Gupta. 2005a. An inventory of herpetofauna of Madhya Pradesh and Chhattisgarh. Zoos' Print Journal 20: 1812-1819.

Chandra, K. and Y. N. Gupta. 2005b. East Indian leopard gecko (Eublepharis hardwickii Gray) found in Pachmarhi Biosphere Reserve (Eublepharidae: Sauria: Squamata). Reptile Rap, Newsletter of the South Asian Reptile Network 7: 2.

Das, I. 1997. Resolution of the systematic status of Eublepharis macularius fuscus Börner, 1981 (Eublepharidae: Sauria: Squamata). Hamadryad 22: 13-20.

Giri, V. B. 2008. A new rock dwelling Hemidactylus (Squamata: Gekkonidae) from Maharashtra, India. Hamadryad 32: 25-33.

Giri, V. B., A. M. Bauer. 2008. A new ground-dwelling Hemidactylus (Squamata: Gekkonidae) from Maharashtra, with a key to the Hemidactylus of India. Zootaxa 1700: 21-34.

Giri, V. B., A. M. Bauer, R. Vyas, and S. Patil. 2009. New species of rock-dwelling Hemidactylus (Squamata: Gekkonidae) from Gujarat, India. Journal of Herpetology 43: 385-393.

Grismer, L. L. 1991. Cladistic relationships of the lizard Eublepharis turcmenicus (Squamata: Eublepharidae). Journal of Herpetology 25: 251-253.

Grismer. L. L. 1988. Phylogeny, taxonomy, classification, and biogeography of eublepharid geckos. Pp. 369-469 in R. Estes and G. K. Pregill (eds.), Phylogenetic
Relationships of the Lizard Families. Stanford University Press.

Grismer. L. L. 1989. Eublepharis ensafi Baloutch and Thireau, 1986: a junior synonym of Eublepharis angramainyu Anderson and Leviton, 1966. Journal of Herpetology 23: 94-95.

Jonniaux, P. and Y. Kumazawa. 2008. Molecular phylogenetic and dating analyses using mitochondrial DNA sequences of eyelid geckos (Squamata: Eublepharidae). Gene 407: 105-115.

Khujaria, H. 1986. On the habits of some central Indian lizards with morphological notes on Eublepharis hardwickii Gray. Records of the Zoological Survey of India 83: 19-23.

Mirza, Z. A. and R. Upadhye. 2010. Zur Verbreitung und Lebensweise des in Indienendemischen Lidgeckos Eublepharis fuscus Börner 1981. Sauria 32: 15-23.

Mirza, Z. A. and R. V. Sanap. 2014. A new cryptic species of gecko of the genus Hemidactylus Oken, 1817 (Reptilia: Gekkonidae) from Southern India. Taprobanica 6: 12-20.

Mirza, Z. A., S. Pal, H. S. Bhosale, and R.V. Sanap. 2014. A new species of gecko of the genus Cnemaspis Strauch, 1887 from the Western Ghats. Zootaxa 3815: 494-506.

Ota, H., M. Honda, M. Kobayashi, S. Sengoku, and T. Hikida. 1999. Phylogenetic relationships of eublepharid geckos (Reptilia: Squamata): a molecular approach. Zoological Science 16: 659-666.

Sharma, R. C. 1980. Discovery of a luminous geckonid lizard from India. Bulletin of the Zoological Survey of India 3: 111-112.

Smith, M. A. 1935. The fauna of British India, including Ceylon and Burma. Reptilia and Amphibia. Vol. II. Sauria. London. Taylor and Francis. 440 pp.

Uetz, P. and J. Hošek. 2014. The Reptile Database. Accessible at http://www.reptile-database.org. Accessed on 23 May 2014. 
Appendix I. Material examined.

Eublepharis angramainyu: CAS 86384 (holotype), Masjid-i-Suleiman and Batwand, Khuzistan Province, Iran.

Eublepharis fuscus: BNHS 1047 (neotype) male, Rajkot, Gujarat, India; BNHS 222 male, Khandesh, Maharashtra, India; BNHS 222 male, Khandesh, Maharashtra, India; BNHS 224 male, Ahmadnagar, Maharashtra, India; BNHS 229 male, Pune, Maharashtra, India; BNHS 226 female, Rajkot, Kathiawar, Gujarat, India; BNHS 936 female, Pune, Maharashtra, India. NCBS AG802, skull of adult male, from Dhule district, Maharashtra.

Eublepharis macularius: ZSIK 6224 (holotype) male, Punjab Salt Range, Pakistan; ZSIK 5840 male, Rajanpur, Trans-Indus, Pakistan; ZSIK 5892 female, Karachi, Pakistan; ZSIK 5884 male, Sind, Pakistan; ZSIK 5958 male, Karachi, Pakistan; BNHS 234 female, Fort Sandeman, Balochistan, Pakistan.

Eublepharis hardwickii: ZSIK 4121 male, Khurda, Odisha; ZSIK 23726 male, Odisha; BNHS227 female, Jaipur, Rajasthan (Likely from Jaypore, Odisha); BNHS 855 male, Bara jamda, Singbhum, Jharkhand, India.

Eublepharis turcmenicus: CAS 184771, Ashgabad, Krasnovodsk Region, Turkmenistan.

Editor: Ross D. MacCulloch 